\title{
CATER FOR PROPER ENGLISH PRONUNCIATION IN THE PRIMARY SCHOOL LEVEL: PUT TO USE ARABIC CONSONANTS
}

\author{
Rosalin Ismayoeng Gusdian*, Riski Lestiono \\ Pendidikan Bahasa Inggris, FKIP Universitas Muhammadiyah Malang, Jl Tlogomas 246 Malang, Indonesia \\ *Corresponding author: rosalindedy@gmail.com
}

\section{INFORMASI ARTIKEL}

ABSTRAK

\section{Sejarah Artikel}

Diterima: 6/10/2019

Direvisi: $3 / 12 / 2019$

Diterima: 4/12/2019

Tersedia Daring: 30/12/2019

Kata Kunci

Bunyi Konsonan Hijaiyah

Bunyi Konsonan Bahasa Inggris

Sekolah Dasar

Penelitian ini bertujuan untuk mendiskusikan bagaimana bunyi konsonan Hijaiyah diperkenalkan dalam pengajaran pronunciation di kelas Bahasa Inggris siswa sekolah dasar. Penelitian ini menggunakan desain penelitian kualitatif. Subjek penelitian adalah dua guru Bahasa Inggris dari Sekolah Dasar Islam di Malang; kedua guru tersebut masing-masing mengajar kelas satu dan dua. Pengumpulan data dilakukan dengan menggunakan teknik observasi dan wawancara. Data yang diperoleh kemudian ditranskripsi, ditinjau, dan dieksplorasi dengan cermat. Hasil penelitian mengungkapkan bahwa ada tiga teknik yang digunakan dalam pembelajaran pronunciation, yaitu drilling, sound imitation, dan tes. Selain itu, masing-masing teknik diintegrasikan ke dalam kegiatan $E Y L$, melalui: menyanyikan lagu, mendongeng, dan permainan.

\section{ABSTRACT}

\section{Keywords}

Arabic Consonant Sounds

English Consonant Sounds

Elementary School Level
This current study aims at revealing how Hijaiyah sounds are introduced in teaching pronunciation in English class of elementary school students. The qualitative research design was employed, and the research subjects were two English teachers of an Islamic elementary school in Malang who taught grade one and two. The data were collected through classroom observation and interview. The data were then transcribed, reviewed, and explored to obtain a meticulous analysis. The results revealed that there are three techniques that are mainly used in the pronunciation class, namely drilling, sound imitation, and test. Besides, each of the pronunciation techniques is integrated into typical EYL activities, namely: singing songs, storytelling, and games.

Copyright@2019, Rosalin Ismayoeng Gusdian, Riski Lestiono This is an open access article under the CC-BY-3.0 license
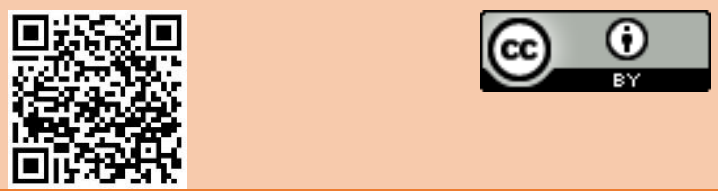

\section{INTRODUCTION}

English has no longer been a compulsory subject for elementary school students in Indonesia. Moreover, according to the enacted 2013 Curriculum (K13 curriculum), English is categorized as an extracurricular subject in which the materials cannot be classified to any regular subjects. It results in such an irony - the lack of exposure in English for elementary school students (R Lestiono \& Rosalin Ismayoeng Gusdian, 2017; Setyaningrum \& Sabilah, 2017). On the other hand, English has undeniably been perceived as an international language for communication. It is proven from the fact that the number of its non-native speakers even exceeds that of its native speakers (Crystal, 2012; Jenkins, 2002). This reality indicates the importance of English language skill mastery to catch up with the era of industrial revolution 4.0. in which English is used in all aspects of technology, such as communication technology, 
transportation technology, education technology, etc. Therefore, it is deemed pivotal that Indonesia prepares its students with sufficient English competence as early as possible. Unfortunately, with the condition as mentioned earlier of English, it might seem to be challenging, especially with the elementary school level.

Some of the significant challenges stemming from the status of English as an extracurricular subject are the insufficiency of English materials for the elementary school level and the lack of teacher creativity (R Lestiono \& Rosalin Ismayoeng Gusdian, 2017; Riski Lestiono, Sumarsono, \& Setyaningrum, 2014; Setyaningrum, Gusdian, Sabgini, \& Hima, 2018; Setyaningrum \& Sabilah, 2017). It is also stated in (Setyaningrum \& Sabilah, 2017) that the main activity in the English classroom is only limited to finishing exercises in the students' workbook (Lembar Kerja Siswa) — which is not written by the teacher, but rather the students buy it from a particular publishing company assigned by the school. Besides, the exercises in the workbook mainly focus on grammar constructions, not the skills of the language. As a result, many elementary school students still find it challenging to master skills and language aspects such as reading, listening, speaking, writing, vocabulary, and pronunciation (Setyaningrum \& Sabilah, 2017). Regarding this matter, EYL practitioners have written supplementary sources to assist elementary school teachers, such as Bilingual Nusantara Folklores (R Lestiono \& Rosalin Ismayoeng Gusdian, 2017), Shining English (Setyaningrum et al., 2018), Little Sunshine Bilingual Book (Setyaningrum et al., 2018), and EnglishHijaiyah Consonant Corresponding Chart. These sources contain various materials like songs and short stories that can be used to teach English skills and language aspects; in addition, the materials can also be integrated into elementary school students' regular thematic learning as stated in K13 curriculum (R Lestiono et al., 2018; Setyaningrum \& Sabilah, 2017). Among these materials, copyrighted English-Hijaiyah Consonant Corresponding Chart is particularly applicable to be used as a source to teach pronunciation.

English-Hijaiyah Consonant Corresponding Chart is a result of a series of researches by Lestiono and Gusdian (2017);2017b), Gusdian and Lestiono (2018); and Lestiono and Gusdian (2018). In the piloting study, it has been initially unveiled that Indonesian students find it bothersome to pronounce English words (Lestiono and Gusdian,(2017). It is due to the difference between English and Bahasa, in which some sounds exist in English, but not in Bahasa and vice versa. Then in the further study, Lestiono and Gusdian (2017) reveal that Arabic sounds are proven to facilitate Indonesian EFL students to pronounce English words as Arabic.

In connection with the aforementioned studies, Gusdian and Lestiono (2018) conduct the follow-up studies to expose how Arabic sounds are introduced in order to facilitate the Indonesian tertiary and secondary EFL students, respectively. Both studies show positive results in which some Arabic sounds represented in the Hijaiyah letters can help Indonesian students in both levels to pronounce several targeted English sounds. Furthermore, in implementing the Arabic sounds to the English classroom, the teachers mainly raise the students' knowledge of several English sounds which do not occur in Bahasa through a short story laden with the targeted sounds which exist in both Arabic and English. After that, they train the students using English-Hijaiyah Consonant Corresponding Chart until they eventually come to an accurate English pronunciation.

In the previous studies, it is clear that the discussion mainly focuses on the application of Hijaiyah sounds in facilitating Indonesian students in higher and secondary education levels. However, the application of such a method in the level of elementary school has not been examined yet. Elementary school students may become an intriguing subject for research because many Indonesian elementary school students still attend Al-Qur'an learning centers (Taman Pendidikan Al-Qur'an/TPQ) after school where they are supposedly exposed to 
Hijaiyah sounds. Accordingly, it is the aim of this current study to discuss how Hijaiyah sounds are used to facilitate the elementary school students to pronounce English words correctly through the help of English-Hijaiyah Consonant Corresponding Chart.

The development of English-Hijaiyah Corresponding chart has started since Lestiono and Gusdian (2017) carried out a piloting study about how Arabic consonants might assist Indonesian EFL students to pronounce English words. In conducting the study, two groups of English department students were taken-one group consisted of students who were familiar with Arabic and another consisted of students who were hardly or even not exposed to Arabic at all. The result of the study has revealed that the students with a good knowledge of Arabic tend to pronounce the targeted English words correctly; whereas the students with little acquaintance with this Semitic language are prone to make more errors. This error may be related to the difference between English and Bahasa in which some consonants in English are not found in Bahasa and the other way around. Meanwhile, some sounds in English are known to be also found in Arabic, and the students who learn Arabic may recognize them quite well. Therefore, it suggests that the students' knowledge of Arabic may help them to pronounce some English words accurately.

In the subsequent study, Lestiono and Gusdian (2017) discuss the students' strategy in using Hijaiyah sounds when they pronounce several targeted words in English. The focused words are the selected words containing sounds which do not exist in Bahasa. For example, 'thumb' and 'birthday' with the sound of $/ \theta /$; 'brother' and 'weather' which constitute the sound of /ð/; 'shoot' and 'ship' containing / $/$. The result reveals that the students who know Arabic tend to use their knowledge of Hijaiyah to pronounce the targeted words because the sounds are present in both Arabic and English. However, they seem not aware that they have such knowledge. Consequently, Lestiono and Gusdian (2017) design a mind map of EnglishHijaiyah corresponding consonant sounds which includes the sounds found in the previous study, i.e., / / / symbolizing ث; / ð/ symbolizing / ذ/; and / $/$ / symbolizing / ش/. The mind map is improved later with the addition of two sounds, namely /dz/ symbolizing / hcihw /z/ dna $/ \mathrm{a}$ symbolizes $/ j /$. The addition of two sounds is instigated from the findings in Gusdian and Lestiono (2018).

Along with the additional sounds, the Hijaiyah-English consonant corresponding chart contains five similar consonant sounds as can be seen in Figure 1.

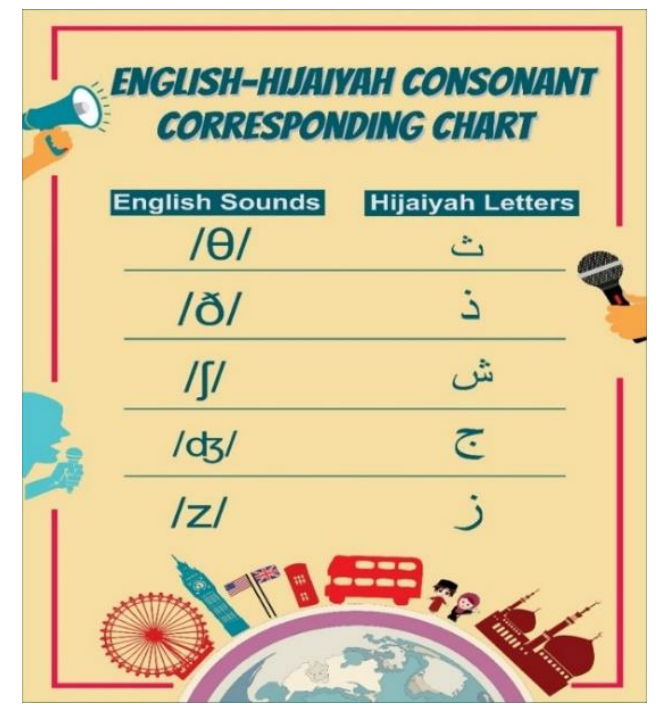

Figure 1. English-Hijaiyah Consonant Corresponding Chart (Gusdian \& Lestiono, 2018) 
The chart has already been copyrighted and implemented in various levels of education except for the elementary school level (Gusdian \& Lestiono, 2018; Riski Lestiono \& Rosalin Ismayoeng Gusdian, 2017).

The standard of pronunciation activities in the classroom normally constitutes specific produced tasks and pronunciation games. The specific produced tasks include activities like minimal pair drills, reading aloud, and sentence practice. In addition to these particular tasks, fun activities such as pronunciation games and tongue twisters are commonly practiced by English teachers when they focus on pronunciation. However, Hismanoglu and Hismanoglu (2010) argue that the aforementioned classical pronunciation activities focus merely on pronunciation accuracy. Not all students can keep up with such activities, as some might understand; yet, some others might find it challenging to learn. Different activities are therefore deemed needed; these activities focus on not only the correctness of pronunciation but also students' fluency. Such activities mainly employ authentic materials like stories, movies, songs, videos, vlogs, and radio streaming. Moreover, all of the authentic materials are currently accessible through the use of technology and social media.

Brown (2007) mentions the use of a continuum of techniques in teaching. He asserts that broad ranges of technique types from the manipulative to the communicative one may be used in any learning activity. There are three types of techniques, namely controlled, free, and guided techniques. The controlled technique emphasizes on the dominant roles of the teachers in controlling and manipulating the classroom's learning activities. Therefore, the students' responses in the controlled class are commonly predicted. Some samples of activities representing the controlled technique are repetition drilling, listening, sound/audio and visual recognition, tactile/kinesthetic practice, question and answer, and minimal pair activities.

Meanwhile, the free technique is quite the opposite. Unlike the controlled technique, which wholly depends on teachers, this technique accentuates students' roles as they encompass various ranges of open-ended activities, which are unpredictable. In other words, the free technique comprises practical and communicative performances in which teachers cannot control their students' responses to a certain extent. The examples of free activities are drama, role-play, presentation, game, and class discussion. Turning to guided technique (as known as semi-controlled technique), Brown (2007) posits that this technique fits in within a certain area between both ends - controlled and free techniques. Guided technique involves blended features of the two techniques mentioned above, in which the activities in this technique may be structured and open-ended at the same time; for instance, question and answer activity with students' feedback and audio recognition with a mutual exchange among students.

In terms of the authentic use of the three techniques in the classroom, Baker (2014) reveals in her study of five ESL teachers that controlled technique is the most frequently used one in their pronunciation class. Among activities in the controlled technique, the most common activities are production practice, drills, visual identification, and testing. Further, she states that many teachers tend to spend more time in giving explanation and example, also checking students' work. On the other hand, the least common technique employed by teachers in teaching pronunciation is guided technique. This suggests that the teachers' knowledge in incorporating such a technique in the classroom activities may be insufficient.

Experts in Psychology from Tufts University divide children into four categories, namely infants ( 0 to 2 years of age), early childhood (2 to 6 years of age), children ( 6 to 13 years of age) and adolescents (13 to 16 years of age). Meanwhile, Scott and Ytreberg (2004) categorize children aged 5 to 7 as young learners level one or beginners, and 8-10-year-old children as young learners level two. Juhana (2014) posits that children are observable from two different standpoints, namely biological and social. In terms of biological perspectives, 
Inhelder and Piaget (1972) mentions stages in children's development, i.e., sensory-motor stage ( 0 to 2 years old); pre-operational stage (2-7 years old); concrete operational stage (711 years old); and formal operational stage (11 years old to adolescences). In terms of the social perspective, Pinter (2017) describes that children are human beings that need any favor of other people to develop their knowledge. Further, with regards to second or foreign language learning, some scholars (Pinter, 2017; Scott \& Ytreberg, 2004) discuss a number of characteristics of young learners, such as they use logical reasoning; they have a considerably short attention span; they use language skills without being aware of them; they use concrete imagination; they are curious about learning new things; they learn in naturally practical and contextualized environment; they construct their knowledge from their own experiences; and they learn effectively in a non-competitive environment.

\section{METHOD}

In this study, a qualitative research design was employed to dig out detailed information about how Arabic consonant sounds were utilized in the elementary school classroom. The research subjects were two English teachers of an Islamic elementary school in Malang who taught grade one and two. The consideration of taking the teachers was that they teach between 7 and 8-year-old students (English for beginners). Besides, they were from an Islamic school in which the students were extensively exposed to Arabic in their daily activities, such as reciting Quran and learning Hijaiyah. It, therefore, is highly presumable that the students are strictly familiar with Arabic sounds.

The study was conducted from April to May 2019. Before the study, the teachers were introduced to the English-Hijaiyah consonant corresponding chart; they were shown how to implement the chart and how it was implemented in tertiary and secondary levels of education (Gusdian \& Lestiono, 2018). Later, in conducting the study, observation, and document analysis (lesson plans) were employed. The observation was conducted twice as the researcher found the repeated data in the first and second meetings. Then, the data from the observation were then matched with those obtained from the lesson plan as the data validation.

\section{FINDINGS AND DISCUSSION}

\section{English-Hijaiyah Sounds in EYL Classrooms}

As both research subjects teach English for beginners, they share the same lesson plan and teaching materials. Besides, they are given autonomy to choose which sounds to be used and taught first before the others. As a result, the following table shows all sounds used in the classroom as well as their order.

Table 1. The Sounds Taught in the Classroom

\begin{tabular}{|c|c|}
\hline English Sounds & Hijaiyah Letters \\
\hline$/ \mathrm{J} /$ & ش \\
\hline$/ d z /$ & ج \\
\hline$/$ /व/ & $\dot{j}$ \\
\hline$/ \theta /$ & $\dot{H}$ \\
\hline $\mid \mathrm{z} /$ & $j$ \\
\hline
\end{tabular}

As perceived from the observation and lesson plan, the teachers use all sounds from the chart. The voiceless palato-alveolar fricative $/ \mathrm{d} /$ and voiced palato-alveolar affricate $/ \mathrm{d} /$ are introduced in the first meeting. Subsequently, the voiced dental fricative /ð/, voiceless dental fricative $/ \theta /$, and voiced alveolar fricative /z/ are taught respectively in the second meeting. All of the targeted sounds are embedded in several simple words that the students are easy to 
acknowledge. The words that contain the targeted sounds are 'jump', 'jaw', and 'juice' (/dz/); 'shower', 'shrimp', and 'brush' (/J/); 'father', 'mother', and 'brother' (/ð/); 'thirsty' $(/ \theta /)$; and 'pizza' (/z/).

From the order of appearance, it is noticeable that the teachers introduce the sounds which share similarities, e.g. / / / and /ds/ which share the same place of articulation; and / // and $/ \theta /$ which own the same place and manner of articulation. In many studies, introducing sounds that have similar features usually induces a minimal pair activity (Baker, 2014; Gusdian \& Lestiono, 2018). However, it is not seen in the observed EYL classroom activities.

\section{Teaching English-Hijaiyah Sounds in EYL Classrooms}

The finding shows that pronunciation teaching is entrenched in thematic learning in which the teaching and learning activities are carried out under specific themes. In the first meeting, the theme is daily activity, and the second theme is family picnic. Therefore, the vocabulary that contains the targeted sounds is chosen following the designated themes. For example, 'jump,' 'brush,' and 'shower' are used in theme one about daily activities.

Meanwhile, 'juice,' 'mother,' 'father,' 'brother,' and 'pizza' are words that are relevant to be used in theme two about family picnic. The embedment of the pronunciation material in thematic learning is in line with (R Lestiono et al., 2018; Setyaningrum \& Sabilah, 2017). They argue that English materials can be incorporated into students' thematic learning, as indicated in K13 curriculum.

Turning to the techniques, it is perceived that both teachers implement some techniques that are generally used in EYL classrooms. The techniques are playing games, singing songs, and telling stories. In the first meeting, for example, the teachers use a children song during the whilst-teaching activity. The song used in the activity is a popular song entitled 'This the Way'; however, to achieve the learning goal (in this case is teaching pronunciation using Hijaiyah letters), the lyrics are modified. The teachers decide the vocab from daily activities: jump, shower, jaw, brush, and wash. The song is shown below:

\section{THIS IS THE WAY SONG}

This is the way I say I jump, say I jump, say I jump

This is the way I say jump, using Jim

This is the way I say Shower, say shower, say shower

This is the way I say shower, using Syin

This is the way I say Brush, say Brush, say Brush

This is the way I say Brush, using Syin

This is the way I say Wash, say Wash, say Wash

This is the way I say Wash, using Syin

The targeted Hijaiyah letters are incorporated among the vocabularies used in the lyrics. The students are then drilled to pronounce the words along with the Hijaiyah sounds embedded in such words ('jump' and 'jaw' use/ج//dgim/; and 'shower' and 'show' use/ش//in/). Through the song, the students are subconsciously guided to pronounce the words using certain Hijaiyah sounds; and the students are well aware of the targeted Hijaiyah sounds. It is observable from the way the students produce the targeted words. They can pronounce the words correctly as well as effortlessly as they pay attention to the Hijaiyah sounds embedded in each focused word. In regular pronunciation classes, such a technique is called drilling. In the previous study, Gusdian and Lestiono (2018) also find that drilling is extensively used in the tertiary level. It can be assumed that in the current study, the teachers incorporate the pronunciation drilling 
activity with the typical activities conducted in the EYL classroom by using authentic material, like a song (Hismanoglu \& Hismanoglu, 2010).

Another technique found in the observed EYL classrooms is a sound imitation. It is seen when the teachers show the targeted Hijaiyah sounds and ask the students to repeat the sounds they pronounce. After that, the teachers show the vocabulary list which contains the targeted sounds; for instance, in the second topic about 'Family Picnic', the words are 'juice,' 'father,' 'mother,' 'shrimp,' and 'pizza.' Next, they ask the students to repeat the words. In addition, the sound imitation activity is incorporated into a storytelling activity, in which the teachers tell them a story about a family going to a picnic in a garden by the lake. This technique is in line with Scott and Ytreberg (2004) who state that sound imitation is another typical technique used in the pronunciation classroom. Similar to the previous technique, the sound imitation technique is well merged in the storytelling activity as the representative of EYL classrooms. This supports Hismanoglu and Hismanoglu (2010) with their argument about authentic materials (songs, stories, and videos), which may become alternatives in teaching pronunciation.

Lastly, it is found that the pronunciation activities in the observed classrooms are reinforced with a pronunciation test in the form of games. The games used in the classroom activities are whispering game and matching games. In the whispering game, the students are divided into several groups; then the teachers whisper to the students at the last row about a word that contains one of the targeted sounds. Every member of the group whispers the words to the student next to him/her until the last students in the front row. Eventually, the students at the front row compete to write down which Hijaiyah letter is used in the vocabulary displayed on the board. Meanwhile, in the matching game, the students are given a paper containing the words with the targeted sounds and cards containing the Hijaiyah letters. In groups, they are to match the words and their correct Hijaiyah sounds. The result of the games generally shows that the students get most of the answers right. It indicates that their acquaintance with Hijaiyah sounds may assist them in producing several English sounds. The use of games in the pronunciation class is, to better emphasize, in accordance with Hismanoglu and Hismanoglu (2010).

According to Brown (2007), the teachers apply one kind of technique in their pronunciation class, namely, controlled technique. The controlled technique in this study is represented by drilling, sound imitation, and testing activities. Brown (2007) also argues that the controlled technique focuses on the role of the teacher. In this current study, it is perceived that the roles of the teachers are considerably dominant during the class. They plan and oversee every scenario of the learning process. They also estimate the result of the pronunciation activities. On the other hand, the students are to follow the activities designed by the teacher. The finding of this study also supports Baker (2014), who postulates that the controlled technique is the most frequently used technique employed in pronunciation class.

\section{CONCLUSION}

In conclusion, the techniques used in the pronunciation class of the elementary school level are drilling, sound imitation, and testing. All of the techniques are integrated into typical EYL activities, such as songs, storytelling, and games. Besides, the pronunciation teaching techniques in this study mainly belong to guided technique, in which the teachers take full control over the classroom activities.

\section{REFERENCES}

Baker, A. (2014). Exploring Teachers' Kknowledge of Second Language Pronunciation Techniques: Teacher Cognitions, Observed Classroom Practices, and Student Perceptions. Tesol Quarterly, 48(1), 136-163. 
Brown, H. D. (2007). Teaching by Principles an Interactive Approach to Language Pedagogy. New York: Pearson Education.

Crystal, D. (2012). English as a Global Language. Cambridge: Cambridge University Press.

Gusdian, R. I., \& Lestiono, R. (2018). The Use of Arabic Consonant Sounds to Arrive at English Pronounciation: a Case Study on Indonesian EFL Students in Tertiary Level Erudio (Journal of Educational Innovation), 5(2), 1-9.

Hismanoglu, M., \& Hismanoglu, S. (2010). Language Teachers' Preferences of Pronunciation Teaching Techniques: Traditional or Modern? Procedia-Social and Behavioral Sciences, 2(2), 983-989.

Inhelder, B., \& Piaget, J. (1972). The Psychology of the Child. New York: Basic Books.

Jenkins, J. (2002). A Sociolinguistically Based, Empirically Researched Pronunciation Syllabus for English as an International Language. Applied linguistics, 23(1), 83-103.

Juhana. (2014). Teaching English to Young Learners: Some Points to be Considered. Asian Journal of Education and e-Learning, 2(1), 43-46.

Lestiono, R., \& Gusdian, R. I. (2017). Arriving at English Pronunciation by Means of Arabic Consonant Sounds: A Case Study on EFL Students in Indonesian Context. Paper presented at the 7th International Conference on Literature, Humanities, Social Sciences and Education, Universitas Muhammadiyah Malang.

Lestiono, R., \& Gusdian, R. I. (2017). Tracing Language Transfer: Patterning English Pronunciation Through Arabic Sounds In Indonesia. Erudio Journal of Educational Innovation, 4(1), 1-7.

Lestiono, R., Sabilah, F., Setyaningrum, R., Gusdian, R. I., Kodir, S., Khofiyah, N., .. . Suparmi, K., E. (2018). Pedoman Pembelajaran Interkultural Berbasis Pendidikan Karakter. Malang: UMM Press.

Lestiono, R., Sumarsono, P., \& Setyaningrum, R. W. (2014). Materi Otentik untuk Kelas English for Young Learners di Universitas Muhammadiyah Malang. Jurnal Humanity, 10(1), 124-132.

Pinter, A. (2017). Teaching Young Language Learners. Oxford: Oxford University Press.

Scott, W., \& Ytreberg, L. H. (2004). Teaching English to Children. New York: Longman.

Setyaningrum, R. W., Gusdian, R. I., Sabgini, K. N. W., \& Hima, A. N. (2018). Little Sunshine Bilingual Book: Kumpulan Lagu dan Cerita Anak-Anak Dwibahasa. Malang: UMM Press.

Setyaningrum, R. W., \& Sabilah, F. (2017). Integrasi Materi Otentik dalam Kegiatan Ekstrakurikuler Bahasa Inggris SD. Erudio Journal of Educational Innovation, 3(1), $55-65$. 